Artikel

\title{
INFORMATION SYSTEM STRATEGIC PLANNING FOR M GROUP
}

\author{
Lily Damayanti ${ }^{1}$, Teofilus Sunarsa ${ }^{2}$, Yuki Gunawan ${ }^{3}$ \\ ${ }^{1,2,3}$ Buddhi Dharma University, Information System, Banten, Indonesia
}

\begin{tabular}{l}
\hline SUBMISSION TRACK \\
\hline Recieved: Feb 3, 2020 \\
Final Revision: Feb 18, 2020 \\
Available Online: Feb 26, 2020 \\
KEYWORD \\
\hline M Group, Information System, Strategic \\
Planning \\
CORRESPONDENCE \\
\hline
\end{tabular}

E-mail: lilydama74@gmail.com

\begin{abstract}
A B S T T R A C T
M Group is a company engaged in the field of pharmacy, eye health and food. Along with the rapid growth of the company there are problems of how to make use the Information Technology department as optimal as possible and how to build a blue print of it strategy in handling a variety of issues and programs or initiatives to support the company's business strategy? This study aims to produce a strategic plan for information technology M Group. The research method used is John Ward and Joe Peppard's framework for strategic planning of information technology and Scott A. Bernard's Enterprise Architecture documentation. This study uses SWOT analysis, IT Balance Scorecard and Cost Benefit Analysis as a strategic tool to analyze the needs of Information System on M Group. After conducting the analysis then the Information System(IS) strategic planning is propose for M Group for next years (2020), which includes business strategies IS, IS / IT Management Strategy, Information System(IS) strategy and future application portfolio. The result of analysis and proposed strategies on $\mathrm{M}$ Group documented using the Enterprise Architecture Documentation.
\end{abstract}

\section{INTRODUCTION}

$\mathrm{M}$ Group is a corporate which is engaged in the pharmacy, eye health and food. Marketing target of the company's network are middle class and upper middle customers, offering high-quality and fashionable products.

Rapid growth of the company giving effect to the change in the company's business strategy. It must be followed by a change in strategy on information technology and information systems. Strategic planning in information technology focused on the technology used, the infrastructure and expertise related to IT issues to support business processes.

According to Ward and Peppard [1], strategic information technology / information systems consist of two components: information systems (IS) and information technology(IT). Strategy defines the information system needs of the organization or the 'demand' for information and systems to support the overall business 
strategy. Related to information technology strategy outlines a vision of how the organization's request for information and the system will be supported by technology. Essentially, it is concerned with 'IT supply'.

According to Scott A. Bernard [2], a strategic plan is a high-level policy and planning documents used by the company to document its direction, competitive strategy, the most important objectives, and programs that enable and projects (strategic initiatives).

The planning for information systems is one of the important things in company's management. The use of information technology associated with proper planning will increase the company's business success. Intended use of strategic planning is to ensure that the use of technology and the development of the company in line the company's business strategy, which in the presence of strategic planning / IT can meet all the required aspects and smooth running of the organization [3].

The essence of the strategy, according to Bernard H. Boar [4], is that the eternal struggle of business is a struggle for profit. The one with the more gains wins, the one with the least gains loses.

According to Erica Olsen [5], strategy means consciously choosing to be clear about the direction of your company in relation to what is happening in a dynamic environment.

Strategy is all these - it is perspective, position, plan, and pattern. Strategy is the bridge between policy or high-order goals on the one hand and tactics or concrete actions on the other. Strategy and tactics together straddle the gap between ends and means [6].

An enterprise architecture is a record plan, a blueprint of the permitted structure, settings, configurations, functional groupings / partitions, interfaces, data, protocols, logical functions, integrations, technology, IT resources required to support an enterprise business or function. and the mission of the organization [7].

\section{METHOD}

Frame of mind in conducting research on IS strategic planning at M Group starting from the collection of data and information obtained through interviews and questionnaires to the management and employees of the Group M and observations to the IT division to obtain an information about the business processes running on the company.

The data and information that has been obtained later in the analysis and further measurements using strategic tools such as SWOT Analysis, IT Balanced Scorecard and Cost Benefit Analysis. From the results of these measurements, it can be seen clearly the factors that influence that can determine the direction of IS strategic planning for the next years (2020).

With the IS strategic planning at $M$ Group then we will get a proposal through the standardization of processes, information systems, and new technologies are then documented using EA Documentation. It aims to support business processes and help improve IT infrastructure better.

In planning IT strategy required a methodology that contains methods and techniques to analyze what factors are needed for the IT strategy planning. The methodology used is shown in Figure 1: 


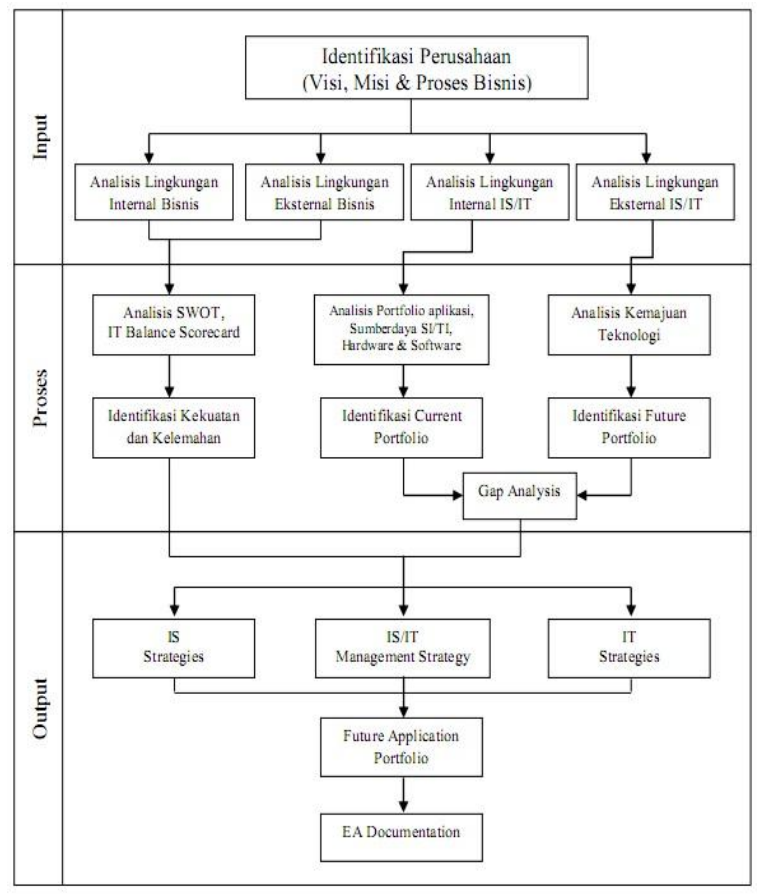

Figure 1: Method2

The translation of the IS strategic planning methodology based on the picture above, there are some models and methods of analysis used in the measurement are:

1. SWOT Analysis

To analyze the internal and external environmental conditions that exist in the optical business unit at M Group use traditional SWOT analysis analyzes the formulation of a strategy to produce in order to maximize opportunities and improve any weaknesses [8].

2. IT Balanced Scorecard (IT BSC)

Analysis IT Balanced Scorecard is used to measure the performance of information technology systems at M Group through 4 perspectives, namely: User Orientation, Operational Excellence, Future Orientation and Business Contribution [9].

3. Internal IT Environment Analysis

Knowing human resources, network, application portfolio, hardware and software that has been owned by the optical business unit at M Group. It is necessary to make comparisons with IT requirements to achieve the company's vision and mission. So in the end it can be concluded that an increase in IT such as what it takes to achieve the set targets.

4. External IT Environment Analysis Knowing the trend of the future of information technology in order to prepare for the needs of the information technology that will be used in accordance with company requirements.

5. Gap Analysis

Analysis of the gap arising from the analysis of the current state of the proposed solutions for future conditions.

6. IT Proposed Strategy

At this stage it will produce output in the form of suggestions concerning the analysis of internal and external M Group, which will provide the output of the result of merging the vision and mission of the company with the development of information and communication technology nowadays. By providing proposals regarding the application portfolio that will come along with the infrastructure to be used to support business processes in the future.

7. Strategic Management of IS / IT With the stage management strategy / IT can create a strategy which can make the measures taken by the top level management related to information technology that will be implemented by the company, in which the policy may be the utilization of human resources, improving the quality of human resources, IT security plan, and the knowledge and skills profile.

8. EA documentation

EA as a translation of the documentation used to document the IT strategy planning optics business unit at M Group:

a) Framework (Framework) 
EA framework is used to identify the scope of the architecture should be documented and made a connection between the existing architecture in the area of optical business unit at $\mathrm{M}$ Group.

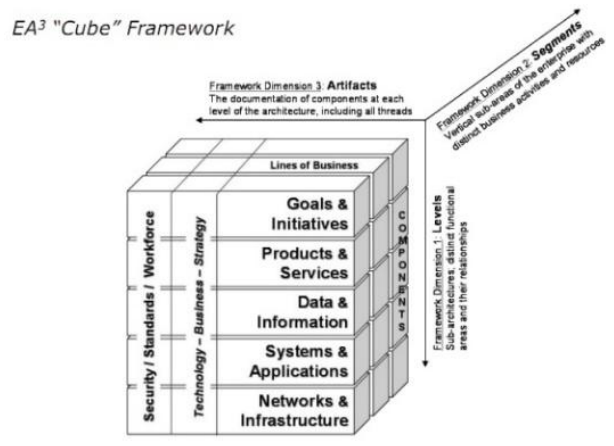

Figure 2: EA Cube Framework [2]

b) Components of Enterprise Architecture EA components are applied to the optical business unit of Group $\mathrm{M}$ is the purpose, process, standards, and resources that will expand the company's business lines.

c) Current Architecture

Current Architecture serves to create a base of resources and activities can be seen now that the gap / difference in performance between the future to the present.

d) Future Architecture

Future Architecture is an IT strategy recommendation for a new future for M Group. Future Architecture obtained after analysis and business done to date is later made changes or updates as needed to support the company's new strategic initiatives, operational or technological needs.

e) EA Management Plan

EA management plan provides a description of the current architectural overview and future, and a series of plans to manage the transition to future business or technology of the future.

f) Planning Threads
Planning 'threads' made up of common activities that exist at all levels of the framework. These threads include IT Security, IT Standards, IT Workforce existing on M Group.

Data collection methods used in the information technology strategic planning at M Group are as follows:

1. Library Study Methods

Library research methods to obtain information that is theoretical, by studying and collecting data through textbooks, articles, journals, internet, including the documents contained in the IT division of Group $M$ associated with this research.

2. Interview

Conducting interviews with management and employees of $\mathrm{M}$ Group to obtain an objective picture of the IS / IT at M Group, after it conducted an analysis of the interview data and to determine what information is needed by management and employees, as a reference to build the IT Strategic proper planning.

3. Observation

Collecting data and information obtained from direct observations on M Group's IT division noted by the authors to obtain important information relating to information technology.

4. Questionnaire

A list of questions used to obtain the data from the source, either through communication or filling the questionnaire by the management and employees of M Group, the purpose of this questionnaire was to find out information about the existing IS/IT in the $\mathrm{M}$ group is already well underway. All data and information obtained from the questionnaire were used as materials to be analyzed further. 


\section{RESULTS AND DISCUSSION}

\section{A. Internal and External Bussiness Environment Analysis of M Group}

SWOT Analysis

SWOT analysis performed at $\mathrm{M}$ Group is used to formulate and choose strategies by comparing internal factors (strengths and weaknesses) and external factors (opportunities and threats). After observing and interviewing M Group's IT Division, SWOT analysis of the obtained results are shown in Table 1 :

Table 1. SWOT Analysis M Group

\begin{tabular}{|c|l|}
\hline Code & \multicolumn{1}{|c|}{ Strengths } \\
\hline S1 & $\begin{array}{l}\text { The top management support the } \\
\text { use of information technology }\end{array}$ \\
\hline S2 & $\begin{array}{l}\text { Hardware, software and } \\
\text { computer networks availability }\end{array}$ \\
\hline S3 & $\begin{array}{l}\text { Exploration is not restricted in } \\
\text { developing an IT project }\end{array}$ \\
\hline S4 & $\begin{array}{l}\text { Budget availability for IT } \\
\text { development }\end{array}$ \\
\hline Code & \multicolumn{1}{|c|}{ Opportunities } \\
\hline O1 & $\begin{array}{l}\text { Information } \\
\text { Development }\end{array}$ \\
\hline O2 & $\begin{array}{l}\text { Changing manual activities to be } \\
\text { computerized }\end{array}$ \\
\hline O3 & $\begin{array}{l}\text { The potential to open new outlets } \\
\text { so that the needs of the IS / IT } \\
\text { becomes very important }\end{array}$ \\
\hline O4 & $\begin{array}{l}\text { Increased need for data and } \\
\text { information }\end{array}$ \\
\hline Code & \multicolumn{1}{c|}{ Weaknesses } \\
\hline W1 & $\begin{array}{l}\text { Data sending from the outlet to } \\
\text { the head office is not maximized }\end{array}$ \\
\hline W2 & Poor network system \\
\hline W3 & The high employee turnover \\
\hline W4 & Poor backup system \\
\hline
\end{tabular}

\begin{tabular}{|c|l|}
\hline Code & \multicolumn{1}{|c|}{ Threats } \\
\hline T1 & $\begin{array}{l}\text { The virus attacks that may } \\
\text { damage system }\end{array}$ \\
\hline T2 & Natural disaster \\
\hline T3 & Piracy of human resources \\
\hline T4 & $\begin{array}{l}\text { Hacker from both internal and } \\
\text { external }\end{array}$ \\
\hline
\end{tabular}

There are 4 strategies of the multiplication between the 4 factors $(\mathrm{S}=$ Strengths, $\mathrm{W}=$ weaknessess, $\mathrm{O}=$ Opportunities, $\mathrm{T}=$ Threats) which will be the strategy SO, ST, WO, and WT.

Table 2. SWOT Analysis Matrix

\begin{tabular}{|c|c|c|}
\hline & Strenghts & Weaknesses \\
\hline \multirow[b]{2}{*}{ 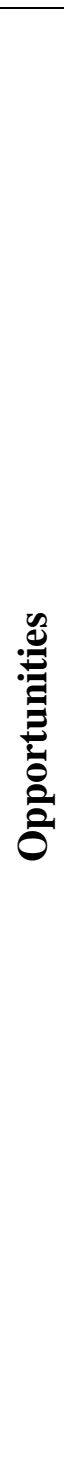 } & SO Strategies & $\begin{array}{c}\text { WO } \\
\text { Strategies }\end{array}$ \\
\hline & $\begin{array}{l}\text { 1. Rebuild the } \\
\text { existing } \\
\text { infrastructur } \\
\text { e using } \\
\text { current } \\
\text { technology } \\
\text { to produce } \\
\text { high quality } \\
\text { data and } \\
\text { information } \\
\text { quality (S1, } \\
\text { S2, S3, S4, } \\
\text { O1, O4) } \\
\text { 2. Create new } \\
\text { applications } \\
\text { to } \\
\text { computerize } \\
\text { manual } \\
\text { activities } \\
\text { (S2, S3, O1, } \\
\text { O2) } \\
\text { 3. Integrating } \\
\text { the data } \\
\text { center to the } \\
\text { outlet by } \\
\text { utilizing }\end{array}$ & $\begin{array}{l}\text { 1. Using } \\
\text { current } \\
\text { information } \\
\text { technology } \\
\text { to create an } \\
\text { effective } \\
\text { method of } \\
\text { data } \\
\text { collection in } \\
\text { order to } \\
\text { generate } \\
\text { high quality } \\
\text { data and } \\
\text { information } \\
\text { (W1, O1, } \\
\text { O3, O4) } \\
\text { structure to } \\
\text { keep abreast } \\
\text { of IT (W2, } \\
\text { W4, O1) } \\
\text { 3. Increase } \\
\text { employee } \\
\text { knowledge } \\
\text { of the data } \\
\text { and } \\
\text { information } \\
\text { needs (W3, }\end{array}$ \\
\hline
\end{tabular}




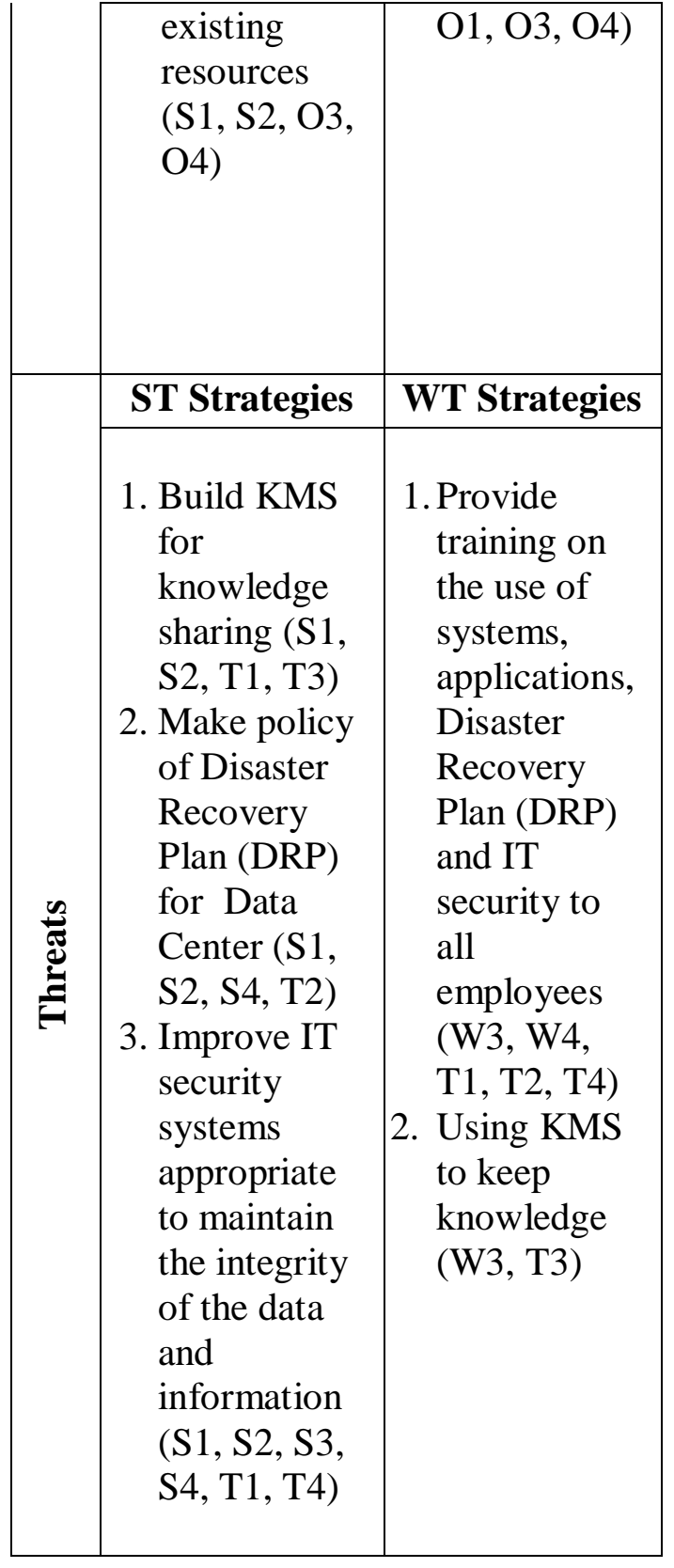

Prepare a SWOT analysis diagram to determine the position of M Group by finding the difference IFAS and EFAS.

$$
\begin{aligned}
\mathrm{X}(\text { internal }) & =\text { strengths }- \text { weaknesses } \\
& =1.74-0.75=0.99 \\
\mathrm{Y}(\text { external }) & =\text { opportunities }- \text { threats } \\
& =1.47-1.98=-0.51
\end{aligned}
$$

It can be described SWOT Analysis diagram as shown in Figure 2:

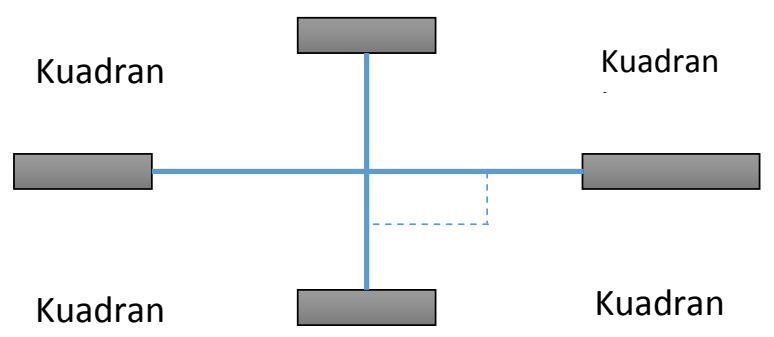

Figure 2: SWOT Analysis Diagram

Based on the results of the SWOT analysis of internal and external factors, M Group is in quadrant II, which means the company's diversification strategy is suggested to overcome the threat of using the internal power held today, the ST strategy as has been shown in table 2 .

\section{IT Balance Scorecard}

\section{Mapping Strategic Objectives to IT Balance Scorecard Perspective}

Formulation of strategic IT objectives derived from IT strategy into four perspectives of IT Balanced

\begin{tabular}{|c|c|}
\hline User Orientation & $\begin{array}{l}\text { Business } \\
\text { Contribution }\end{array}$ \\
\hline $\begin{array}{l}\text { Strategy: } \\
\text { Have the human } \\
\text { resources that are } \\
\text { reliable and } \\
\text { appropriate } \\
\text { implementation. } \\
\text { Able to present the } \\
\text { data and } \\
\text { information quickly } \\
\text { needed and accurately. }\end{array}$ & $\begin{array}{l}\text { Strategy: } \\
\text { Provide, use and } \\
\text { maintain the } \\
\text { network, } \\
\text { infrastructure and } \\
\text { information } \\
\text { systems. } \\
\text { Strategy } \\
\text { objectives: } \\
\text { - Contribution of } \\
\text { IT functions }\end{array}$ \\
\hline
\end{tabular}
Scorecard can be seen in Table 3:

Table 3. The purpose of IT Strategy Formulation 


\begin{tabular}{|c|c|}
\hline $\begin{array}{l}\text { Strategy } \\
\text { objectives: } \\
\text { - Contribution of } \\
\text { IT functions } \\
\text { - Increase user } \\
\text { satisfaction } \\
\text { - Improve the } \\
\text { ability of users }\end{array}$ & \\
\hline $\begin{array}{l}\text { Operational } \\
\text { Excellence }\end{array}$ & $\begin{array}{l}\text { Future } \\
\text { Orientation }\end{array}$ \\
\hline $\begin{array}{l}\text { Strategy: } \\
\text { Provide, use and } \\
\text { maintain } \\
\text { network, } \\
\text { infrastructure and } \\
\text { information } \\
\text { systems. } \\
\text { Strategy } \\
\text { objectives: } \\
\text { - Problem } \\
\text { solving } \\
\text { - Operational } \\
\text { Efficiency } \\
\text { - Efficiency of } \\
\text { application }\end{array}$ & $\begin{array}{l}\text { Strategy: } \\
\text { Provide solutions } \\
\text { to IT problems } \\
\text { quickly and } \\
\text { accurately. } \\
\text { Provide, use and } \\
\text { maintain the } \\
\text { network, } \\
\text { infrastructure and } \\
\text { information } \\
\text { systems. } \\
\text { Strategy } \\
\text { objectives: } \\
\text { - Improved } \\
\text { quality of IT } \\
\text { •Increased } \\
\text { ability } \\
\text { employees } \\
\text { •Develop } \\
\text { applications } \\
\text { and } \\
\text { infrastructure }\end{array}$ \\
\hline
\end{tabular}

\section{Results of Performance Measurement and Evaluation System}

Results of performance measurement system to strategic objectives are achieved at M Group are shown in Table 4:
Table 4. System Performance

Measurement Results

\begin{tabular}{|c|c|c|c|}
\hline Perspektive & $\begin{array}{l}\text { Strategic } \\
\text { Goals }\end{array}$ & Result & Weight \\
\hline \multirow[t]{2}{*}{$\begin{array}{l}\text { Business } \\
\text { Contribution }\end{array}$} & $\begin{array}{l}\text { IT Function } \\
\text { Contribution }\end{array}$ & $60,04 \%$ & Enough \\
\hline & Average & $60,04 \%$ & Enough \\
\hline \multirow[t]{4}{*}{$\begin{array}{l}\text { User } \\
\text { Orientation }\end{array}$} & $\begin{array}{l}\text { Increasing } \\
\text { Customer } \\
\text { Satisfaction } \\
\end{array}$ & $75 \%$ & Good \\
\hline & $\begin{array}{l}\text { Increasing } \\
\text { Users Ability }\end{array}$ & $78,5 \%$ & Good \\
\hline & $\begin{array}{l}\text { Increasing } \\
\text { Users } \\
\text { Productivity }\end{array}$ & $69,6 \%$ & Good \\
\hline & Average & $74 \%$ & Good \\
\hline \multirow[t]{4}{*}{$\begin{array}{l}\text { Operational } \\
\text { Excellence }\end{array}$} & $\begin{array}{l}\text { Problem } \\
\text { solving }\end{array}$ & $71 \%$ & Good \\
\hline & $\begin{array}{l}\text { Operational } \\
\text { Efficiency }\end{array}$ & $62 \%$ & Good \\
\hline & $\begin{array}{l}\text { Leveraging } \\
\text { Application } \\
\text { Efficiency } \\
\end{array}$ & $66 \%$ & Good \\
\hline & Average & $66,3 \%$ & Good \\
\hline \multirow[t]{4}{*}{$\begin{array}{l}\text { Future } \\
\text { Orientation }\end{array}$} & $\begin{array}{l}\text { Increasing IT } \\
\text { Qualiy }\end{array}$ & $76 \%$ & Good \\
\hline & $\begin{array}{l}\text { Increasing } \\
\text { Employer } \\
\text { Ability }\end{array}$ & $77,5 \%$ & Good \\
\hline & $\begin{array}{l}\text { Building IT } \\
\text { system and } \\
\text { infrastructure }\end{array}$ & $80 \%$ & Good \\
\hline & Average & $\mathbf{7 7 , 8} \%$ & Good \\
\hline
\end{tabular}

From the summary of the above performance measurements, it can be concluded that the measurement results from the four IT Balanced Scorecard perspectives show that the performance of the TI M Group is included in the Good category with an average total of $69.54 \%$.

\section{Initiatives and IS / IT Needs based on} the IT Balance Scorecard

After evaluating by measuring the IT Balance Scorecard, the company needs to implement policies and program initiatives to support the IT M 
Group's vision and mission, namely initiatives to build a Knowledge Management System.

\section{B. IS/IT Internal Environment Analysis of M Group}

\section{Current Portfolio Application}

The M Group's IT division manages information system applications mapped using the McFarlan Grid model, seen in table 5:

Table 5. Application Portfolio in McFarlan's Grid Model

\begin{tabular}{|c|c|c|c|}
\hline \multirow{6}{*}{ 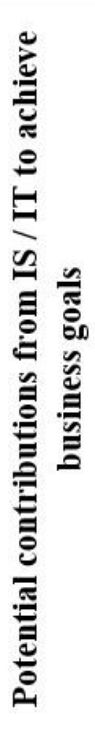 } & \multirow{2}{*}{ 햄ㅁㅁ } & Strategic & High Potential \\
\hline & & & - $\mathrm{CRM}$ \\
\hline & \multirow[b]{2}{*}{$\stackrel{1}{\Leftrightarrow}$} & $\begin{array}{c}\text { Key } \\
\text { Operational }\end{array}$ & Support \\
\hline & & $\begin{array}{l}\text { - Inventory } \\
\text { - Merchand } \\
\text { - Purchase } \\
\text { - Lab } \\
\text { - POS } \\
\text { - Finance } \\
\text { - GL } \\
\text { - HO }\end{array}$ & $\begin{array}{l}\text { - Website m.com } \\
\text { - Email Blast } \\
\text { - SMS Blast } \\
\text { - Helpdesk } \\
\text { Application } \\
\text { - Absensi } \\
\text { - Payroll } \\
\text { - Assets } \\
\text { Management } \\
\text { - Taxes }\end{array}$ \\
\hline & & High & Low \\
\hline & \multicolumn{3}{|c|}{$\begin{array}{l}\text { Dependence on the continuity of } \\
\text { activities on IS / IT }\end{array}$} \\
\hline
\end{tabular}

From the results of the analysis of the portfolio of applications currently running at M Group, it appears that there is one application that has the High Potential characteristic of CRM, this application is used to support marketing and create profit opportunities. Applications in the Key Operations category to support the sustainability of business processes and the company's high dependence on the use of these applications. Applications in the Support Category can support to improve company business but do not provide competitive advantage.

\section{M Groups IS/IT External Environment Analysis}

Based on the analysis of technological trends in 2020 that there is an increasing trend in bringing personal devices and the growth of wireless internet accessors so as to make it easier to access information. $\mathrm{M}$ Group must be able to see these external opportunities to develop business value from the use of the technology.

\section{Gap Analysis}

After conducting an analysis of $\mathrm{M}$ Group's internal and external environment, that is, from the SWOT analysis and the results of the IT Balance Scorecard analysis, an initiative was found to build a Knowledge Management System. Then a gap can be identified between the current state and future system needs. The gap analysis identified is shown in table 6:

Table 6. Gap Analysis

\begin{tabular}{|l|l|}
\hline Solution & Knowledge Management System \\
\hline Needs & $\begin{array}{l}\text { New IT staff can start working } \\
\text { quickly }\end{array}$ \\
\hline Situation & $\begin{array}{l}\text { The current condition is not } \\
\text { possible because there is no } \\
\text { knowledge transfer system from } \\
\text { old staff to new staff, the } \\
\text { knowledge just disappears, so } \\
\text { new staff have to find their own } \\
\text { knowledge for solutions to } \\
\text { problems, so it takes a long time } \\
\text { to solve the problem. }\end{array}$ \\
\hline Future \\
Condition & $\begin{array}{l}\text { New IT staff can work with } \\
\text { guidance from the Knowledge } \\
\text { Management System, so they } \\
\text { can work quickly and precisely } \\
\text { in providing solutions if there } \\
\text { are problems. }\end{array}$ \\
\hline
\end{tabular}




\section{E. Proposed SI / IT Strategy}

\section{Knowledge Management System}

After analyzing the internal and external environment of the M Group, the results obtained from the proposed SI / IT strategy to support the company's activities in achieving the vision and mission, namely creating a Knowledge Management System.

In Figure 2 a picture of the Knowledge Management System architecture design for M Group will be shown, which refers to the Knowledge Management System architecture from Ronald Maier [10]:

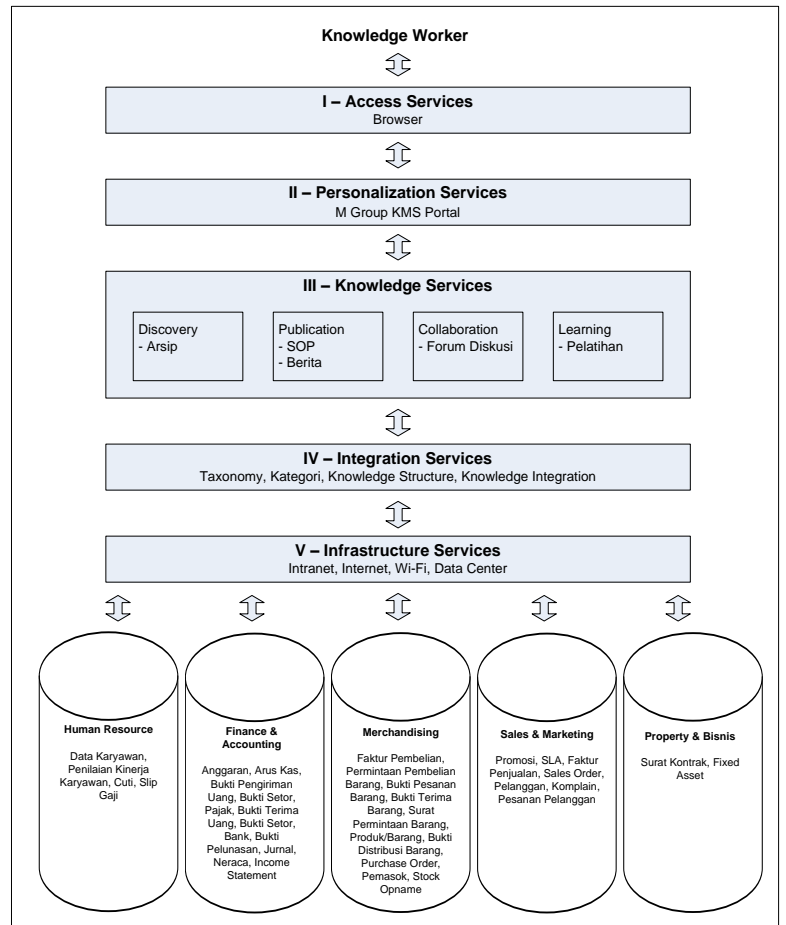

Figure 2. M Group's Knowledge

Management System Architecture

Based on Figure 2 of $M$ Group's Knowledge Management System Architecture, data sources come from databases from each department in the $M$ Group environment, namely human resource, finance \& accounting, merchandising, sales \& marketing and property \& business databases. Furthermore, all sources of data will be deployed using service infrastructure through the internet, intranet, Wi-Fi and Data Center. In integration services, data and information from all initial sources are integrated and data and information are organized. In knowledge

services, functions are provided to be able to find archives, publish SOPs and news, collaborate in the form of discussion forums, and organize learning processes. In personalization services, access is provided to all existing departments by using access services in the form of a browser and finally knowledge will be conveyed to the knowledge worker.

\section{A. Application Proposed Portfolio}

The proposed application that has been designed is then mapped based on the criteria of the potential contribution of IS / IT to achieve business goals and the dependence of the company's ongoing activities on IS / IT. The results of mapping the proposed application portfolio can be seen in table 7:

Table 7. Application Portfolio

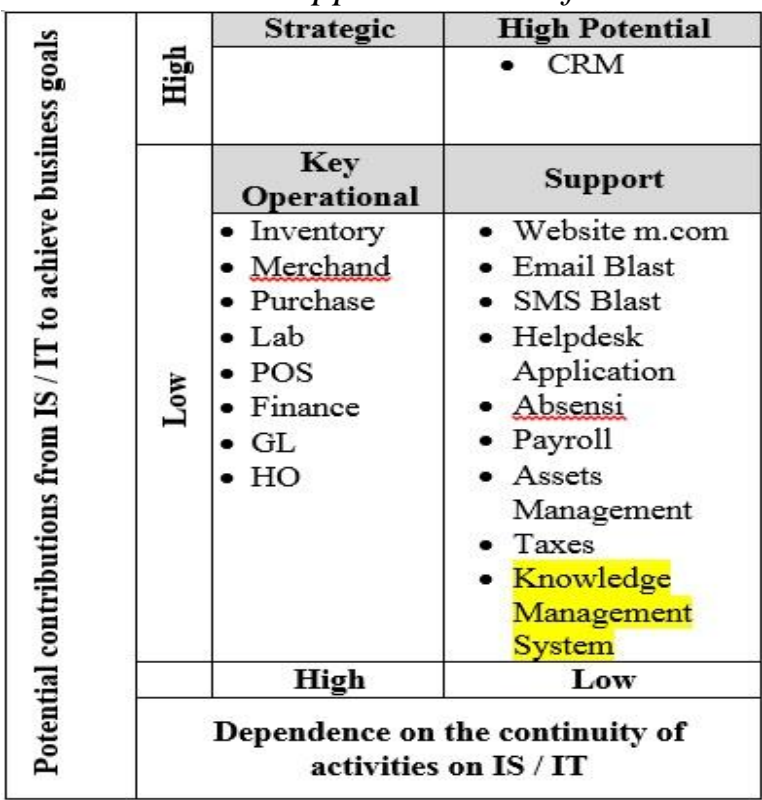




\section{B. Network Infrastructure}

With the proposed Knowledge Management application, infrastructure is needed to support the application. Figure 3 is a picture of the proposed network infrastructure for M Group:

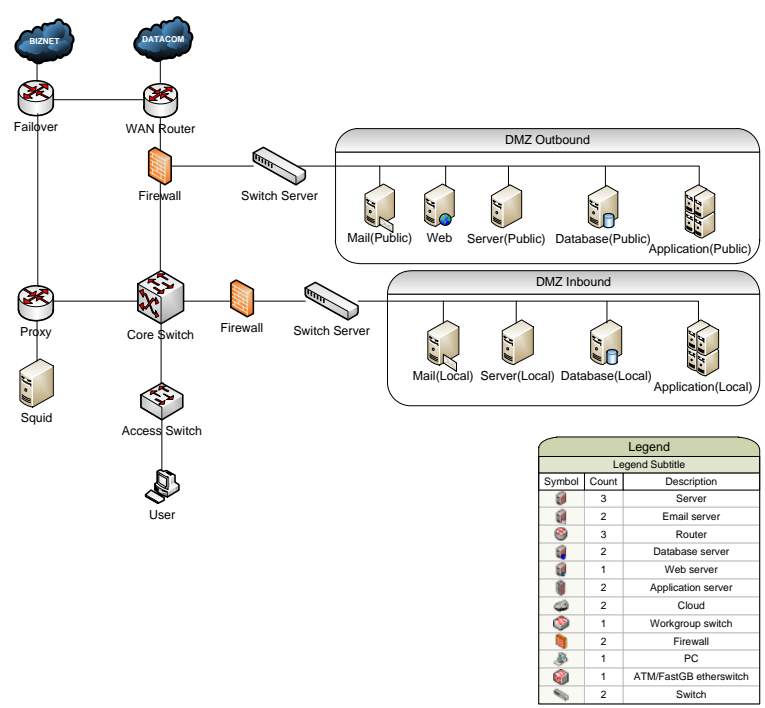

Figure 3. Proposed network infrastructure

It is proposed to add a firewall for internal network servers into the $\mathrm{DMZ}$ Inbound environment. Whereas the firewall for external network servers still enters the DMZ Outbound environment. The addition of a firewall for Inbound DMZ aims to overcome the problem of internal company attacks.

\section{Hardware and Software Infrastructure}

For hardware and software, adjustments are needed especially for DRP. The database server uses a server with the Debian Linux operating system, while the database uses the Progress Database. Table 8 and Table 9 are the following hardware and software specifications table with prices:
Table 8. Hardware Specifications

\begin{tabular}{|c|c|c|c|}
\hline No & Hardware Specification & Price & $\begin{array}{l}\text { Picture } \\
\end{array}$ \\
\hline 1 & 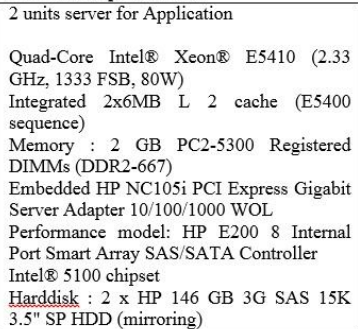 & $\begin{array}{l}\text { @.Rp. } \\
9.000 .000\end{array}$ & | \\
\hline 2 & 1 unit Juniper SSG-550M-SH & $\begin{array}{l}\mathrm{Rp} \\
70.500 .000\end{array}$ & \\
\hline 3 & $\begin{array}{l}5 \text { unit PC } \\
\text { Core i3 } 2120 \mathrm{~T} 2.6 \mathrm{Ghz}, 2 \mathrm{~GB} \text { DDR3, 500GB } \\
\text { SATA, DVDRW, Intel GMA, Card Reader, } \\
\text { K/B + Mouse, Lan, Win } 7 \text { Home Premium }\end{array}$ & $\stackrel{@}{5.500 .000}$ Rp. & \\
\hline & Total & $\begin{array}{l}\text { Rp. } \\
107.000 .000\end{array}$ & \\
\hline
\end{tabular}

Table 9. Software Specifications

\begin{tabular}{|l|l|l|l|}
\hline No & \multicolumn{1}{|c|}{$\begin{array}{c}\text { Software } \\
\text { Specification }\end{array}$} & Price & Picture \\
\hline 1 & $\begin{array}{l}\text { 1 Microsoft Window } \\
\text { Server Standard 2008 } \\
\text { 5 Client Software }\end{array}$ & Rp. 6.400.000 & \\
\hline 2 & $\begin{array}{l}1 \text { MySQL Database } \\
\text { Server }\end{array}$ & $\begin{array}{l}\text { Open Source } \\
\text { (Free) }\end{array}$ & MySQL \\
\hline & Total & Rp. 64.00.000 & \\
\hline
\end{tabular}

\section{Human Resources and Implementation} Plans

Table 10 shows the human resources needed and overall costs for developing the proposed application of the Knowlede Management System:

Table 10. Human Resources and Total Costs

\begin{tabular}{|c|c|c|}
\hline \multicolumn{3}{|c|}{ Knowledge Management Systems } \\
\hline Needs & Duration & Costs \\
\hline 1 System Analyst & 3 months & $\begin{array}{l}1 \times 3 \times \underline{\text { Rp. }} .9 .000 .000= \\
\text { Rp. } 27.000 .000\end{array}$ \\
\hline 2 Programmer & 5 months & $\begin{array}{l}1 \times 5 \times \underline{\text { Rp. }} .5 .000 .000= \\
\text { Rp. } 25.000 .000\end{array}$ \\
\hline $\begin{array}{l}\text { 1 System Tester/ } \\
\text { Implementator }\end{array}$ & 1 month & Rp. 3.500 .000 \\
\hline \multicolumn{2}{|l|}{ User Training Fee } & Rp. 1.000 .000 \\
\hline \multicolumn{2}{|c|}{ Total } & Rp. 56.500 .000 \\
\hline
\end{tabular}




\section{E. IS / IT Management Strategy}

\section{IS / IT Security Plan}

Effective IS / IT security is a solution for companies by implementing IS / IT security programs are divided into 4 areas:

a) Information Security

Make policies to reduce threats.

b) Security Personnel

Authentication of users is required and awareness raising on IS / IT security is through training.

c) Operational Security

Evaluation of IS / IT security risks is required, testing of IS / IT security components, making policy improvements to anticipate vulnerabilities in the system, making policies that govern implementation, making operating standards and procedures, and handling all issues of IS / IT security threats.

d) Physical Security

Policies to regulate personnel access to buildings where IT and non-IT resources exist, regulate access of personnel who can enter the server room, network planning and network cable management by the Network Administrator.

\section{Workforce Plan}

The proposal to improve the professionalism of existing human resources is to conduct training to increase knowledge about the development of information technology, attend seminars on IS / IT organized by software vendors, develop technical skills to communicate with others and practice leadership attitudes.

\section{Knowledge and Skill Profile}

The standard of knowledge and expertise in the M Group is needed for each employee to understand what must be done at the level of his position.

\section{E. Cost Benefit Analysis}

Cost Benefit Analysis is defined as the process of comparing various costs for implementing information systems with the benefits the company gets from using the information system. In order to make it easy to see the difference, it could be a difference if you don't use a new (marginal) information system. This meant that the additional costs incurred for the new system had to be included. Likewise, new or additional benefits must be compared with costs [11].

To compare the various costs for implementing an IS / IT strategy and the IS / IT management strategy with the benefits the company receives from using that strategy, an analysis of the costs will be incurred using the financial model and valuation shown in table 11:

Table 11. Cost Benefit Analysis

\begin{tabular}{|c|c|c|c|}
\hline On-Going Cost & Year 0 & Year 1 & Year 2 \\
\hline Software & 6.400 .000 & 0 & 0 \\
\hline Hardware & 107.000 .000 & 0 & 0 \\
\hline Application Development & 56.500 .000 & 0 & 0 \\
\hline Maintenance Software & 250.000 & 250.000 & 250.000 \\
\hline Maintenance Hardware & 3.600 .000 & 3.600 .000 & 3.600 .000 \\
\hline User Training & 1.000 .000 & 0 & 0 \\
\hline Salary & 0 & 48.000 .000 & 52.800 .000 \\
\hline Total & 174.750 .000 & 51.850 .000 & 56.650 .000 \\
\hline Benefits & Year 0 & Year 1 & Year 2 \\
\hline $\begin{array}{l}\text { Profit from increasing the number of } \\
\text { orders }\end{array}$ & 0 & 200.000 .000 & 200.000 .000 \\
\hline Total Benefits & 0 & 200.000 .000 & 200.000 .000 \\
\hline NET BENEFITS & -174.750 .000 & 148.150 .000 & 143.350 .000 \\
\hline Discount Factor $10 \%$ & 1,00 & 0,91 & $\mathbf{0 , 8 3}$ \\
\hline Discounted Annual Net Benefit & -174.750 .000 & 134.681 .818 & 118.471 .074 \\
\hline NET PRESENT VALUE & 78.402 .893 & & \\
\hline IRR (Internal Rates of Return) & $42 \%$ & & \\
\hline PAYBACK PERIOD & 1,13 & & \\
\hline
\end{tabular}

The assumptions used in the calculation of Cost Benefit Analysis in table 12 are:

- 1 operator is required for KMS maintenance with a salary of Rp $4,000,000$ and assuming a pay rise of $10 \%$

- It is estimated that the number of orders that can be done a month increases by 
1000 orders, assuming a profit per order of $R p 200,000$, then a year profit of $R p$ 200,000,000

- Assuming rates of $10 \%$

Explanation from table 12 of the Cost Benefit Analysis calculation above is as follows:

- Net Present Value

Total Discounted Annual Net Benefit from year 0 to year 2. The NPV has a positive value, meaning that the $\mathrm{M}$ Group's information system strategic planning project is feasible to be implemented.

- IRR (Internal Rates of Return)

The IRR (Internal Rates of Return) function to calculate the interest rate generated from total benefits from year 0 to year 2 , the rates used are $10 \%$. The IRR result for the $\mathrm{M}$ Group information system strategic planning project is $42 \%$, which means the project is feasible to be implemented because it is greater than the assumed rate of $10 \%$.

- Payback Period

Payback Period is obtained from the total information system investment divided by After Tax Profit. The payback period is 1.13 means that the information system investment will return in year 2 .

\section{G. Enterprise Architecture}

The results of the analysis and proposed information systems strategy at $M$ Group are documented using the Scott A. Bernard Enterprise Architecture method [12]. The following is a table consisting of a list of artifacts used to document the analysis and proposed IT strategies for the M Group:
Table 12. EA Artefacts

\begin{tabular}{|c|c|c|}
\hline Level & Artefacts ID & $\begin{array}{c}\text { Artefacts } \\
\text { Name }\end{array}$ \\
\hline \multirow[t]{2}{*}{$\begin{array}{l}\text { Goals \& } \\
\text { Initiatives }\end{array}$} & $S-1$ & $\begin{array}{l}\text { SWOT } \\
\text { Analysis }\end{array}$ \\
\hline & $S-2$ & $\begin{array}{l}\text { IT Balanced } \\
\text { Scorecard }\end{array}$ \\
\hline $\begin{array}{l}\text { Products \& } \\
\text { Services }\end{array}$ & $B-1$ & Rich Picture \\
\hline \multirow[t]{2}{*}{$\begin{array}{l}\text { Data \& } \\
\text { Information }\end{array}$} & $D-1$ & $\begin{array}{l}\text { Activity/Entity } \\
\text { (CRUD) } \\
\text { Matrix }\end{array}$ \\
\hline & $D-2$ & $\begin{array}{l}\text { Class } \\
\text { Diagram }\end{array}$ \\
\hline \multirow[t]{4}{*}{$\begin{array}{l}\text { Systems \& } \\
\text { Applications }\end{array}$} & $S A-1$ & $\begin{array}{l}\text { Use Case } \\
\text { Diagram }\end{array}$ \\
\hline & $S A-1$ & $\begin{array}{l}\text { Sequence } \\
\text { Diagram }\end{array}$ \\
\hline & $S A-3$ & User Interface \\
\hline & $S A-4$ & $\begin{array}{l}\text { Portfolio } \\
\text { Aplikasi }\end{array}$ \\
\hline $\begin{array}{l}\text { Technology \& } \\
\text { Infrastructure }\end{array}$ & $N-1$ & $\begin{array}{l}\text { Network } \\
\text { Connectivity } \\
\text { Diagram }\end{array}$ \\
\hline Security & $S P-1$ & $\begin{array}{l}\text { IT Security } \\
\text { Plan }\end{array}$ \\
\hline Standards & $S T-1$ & $\begin{array}{l}\text { Hardware \& } \\
\text { Software }\end{array}$ \\
\hline \multirow[t]{2}{*}{ Workforce } & $W-1$ & $\begin{array}{l}\text { Workforce } \\
\text { Requirement }\end{array}$ \\
\hline & $W-2$ & $\begin{array}{l}\text { Knowledge \& } \\
\text { Skills Profile }\end{array}$ \\
\hline
\end{tabular}

According to James Martin [13], clustering matrix (Activity/Entity (CRUD) Matrix) is a type of matrix function that is grouped to show which data function and data match.

\section{CONCLUSIONS}

From the analysis and design of information technology strategic M Group, can be concluded as follows:

1. Proposed IS/IT strategy period 2020 for M Group, covering business strategies IS, IS / IT Management Strategy, strategy and future IT application portfolio. The strategy generated through internal environment analysis process and the external environment by using SWOT analysis and IT Balanced Scorecard. 
2. Based on the analysis of the internal environment and the external environment M Group by using SWOT analysis, M Group is in ST quadrant with coordinates $(0.99,-0.51)$, which means that the company must implement diversification strategies that address the threat by using the internal power possessed today.

3. Based on the analysis using IT Balanced Scorecard, showing that the performance of the IT section M Group included in the Good category with a total average of $69.54 \%$, which means that companies need to implement policies and program initiatives to support the vision and mission of IT M Group.

4. Mapping portfolio applications using McFarlan's Grid, which has potential applications are divided into four categories: strategic, high potential, key operational, and support.

5. Proposed Application of Knowledge Management System built to facilitate knowledge sharing within the M Group where the KMS application is provided by the function to be able to find records, standard operating procedures and news publishing, collaboration in the form of discussion forums, and organize the learning process.

6. The analysis and proposals on M Group's IT strategy is documented using the Enterprise Architecture Scott A. Bernard.

\section{ACKNOWLEDGEMENT}

The authors would like to express our gratitude for the support provided by Faculty of Science and technology. The financial assistance from Research, Publication and Community Service Department Buddhi Dharma University is also greatly acknowledged.

\section{REFERENCES}

[1] Ward, John; Peppard, Joe. (2002). Strategic Planning for Information System (Third Edition ed.). Cranfield, Bedfordshire, UK: John Wiley \& Sons, Ltd.

[2] Bernard, S. A. (2005). An Introduction to Enterprise Architecture: Second Edition. Bloomington, IN: AuthorHouse.

[3] Al-Aboud, F. N. (2011). Strategic Information Systems Planning : A Brief Review. IJCSNS International Journal of Computer Science and Network Security , 11.

[4] Boar, B. H. (2001). The Art of Strategic Planning for Information Technology. New York: John Wiley \& Sons, Inc.

[5] Olsen, E. (2007). Strategic Planning for Dummies. Indiana: Wiley Publishing Inc.

[6] Nickols, F. (2012). Strategy: Definitions \& Meanings.

[7] Minoli, D. (2008). Enterprise Architecture A to Z. Boca Raton: Auerbach Publications, Taylor \& Francis Group.

[8] Rangkuti, F. (2000). Analisis SWOT Teknik Membedah Kasus Bisnis. Jakarta: PT Gramedia Pustaka Utama.

[9] Grembergen, W. V., \& Saull, R. (2001). Aligning Business and Information Technology through the Balanced Scorecard at a Major Canadian Financial Group: its Status Measured with an IT BSC Maturity Model. IEEE .

[10] Maier, R. (2007). Knowledge Management System. New York: Springer.

[11] Sugiyono. (2011). Metode Penelitian Kombinasi (Mixed Methods). Bandung: Alfabeta. 
[12] Bernard, S. (2006). Using Enterprise Architecture to Integrate Strategic, Business, and Technology Planning. Journal of Enterprise Architecture .

[13] Martin, J. (1989). Information Engineering Book II: Planning \& Analysis. Prentice Hall.

\section{BIOGRAPHY}

Lily Damayanti, Graduated from the Computerized Accounting Study Program (S1) at Binus University in 1997, continued her Master Degree in Magister Information Technology at Binus University in 2011 and graduated in 2013. She is currently a Lecturer in Information Systems Study Program, Buddhi Dharma University.

Teofilus Sunarsa. Started education at STMIK Buddhi Tangerang in 2008 for Bachelor Degree in Information of Technology. After graduated from STMIK Buddhi, registered in School of Technology Eresha for Master Degree in Management Information System. And now as a lecture at Buddhi Dharma University in Information System Department.

Yuki Gunawan, He is currently a Lecturer in Information Systems Study Program, Buddhi Dharma University. 